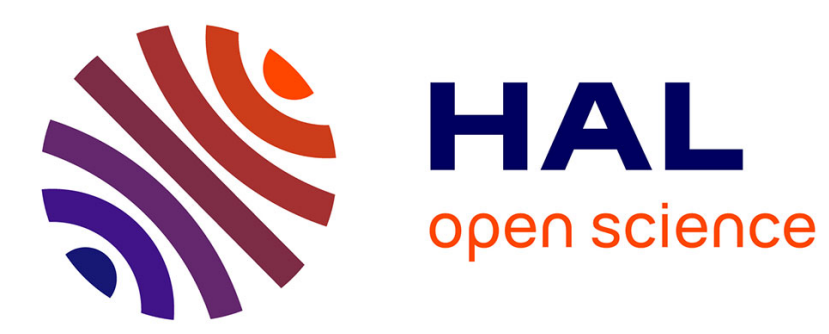

\title{
The construction is/bið to: a syntactic formula to express prescription and earmarking \\ Olivier Simonin
}

\section{To cite this version:}

Olivier Simonin. The construction is/bið to: a syntactic formula to express prescription and earmarking. Elise Louviot. La Formule au Moyen Age, Brepols, pp.89-104, 2012, 978-2-503-54749-7. hal-02433453

\section{HAL Id: hal-02433453 \\ https://hal-univ-perp.archives-ouvertes.fr/hal-02433453}

Submitted on 22 Apr 2021

HAL is a multi-disciplinary open access archive for the deposit and dissemination of scientific research documents, whether they are published or not. The documents may come from teaching and research institutions in France or abroad, or from public or private research centers.
L'archive ouverte pluridisciplinaire HAL, est destinée au dépôt et à la diffusion de documents scientifiques de niveau recherche, publiés ou non, émanant des établissements d'enseignement et de recherche français ou étrangers, des laboratoires publics ou privés. 
La Formule au Moyen Âge

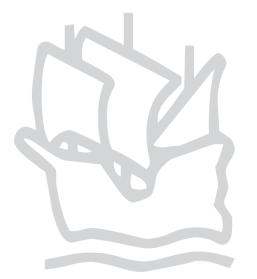

(C) BREPOLS PUBLISHERS

THIS DOCUMENT MAY BE PRINTED FOR PRIVATE USE ONLY.

IT MAY NOT BE DISTRIBUTED WITHOUT PERMISSION OF THE PUBLISHER. 


\begin{abstract}
ARTEM
Atelier de Recherche sur les Textes Médiévaux
\end{abstract}

15

La collection est publiée à Nancy par le Centre de médiévistique Jean-Schneider (Université de Lorraine-CNRS) 


\title{
La Formule au Moyen Âge
}

Sous la direction

d'Elise Louviot

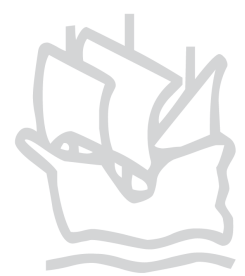

\section{BREPOLS}

\author{
(C) BREPOLS PUBLISHERS
}




\section{Comité scientifique :}

Sylvie Bazin (Professeur, Université de Lorraine)

Christelle Cazaux-Kowalski (Maître de conférences, Université de Poitiers)

Catherine Delesse (Professeur, Université de Lorraine)

Flavia De Rubeis (Professeur associé, Università degli Studi di Venezia, Ca' Foscari)

Isabelle Draelants (Directrice de Recherche CNRS, Centre de Médiévistique Jean-Schneider,

Nancy)

Thomas Falmagne (Chercheur, Bibliothèque nationale du Luxembourg, Bibliothèque universitaire de Francfort)

Cédric Giraud (Maître de conférences, Université de Lorraine et Institut Universitaire de France)

Hervé Le Bihan (Professeur, Université de Rennes)

Michel Lefftz (Professeur, Facultés universitaires Notre-Dame de la Paix à Namur)

Elise Louviot (Docteur, Université de Lorraine)

Laurence Moulinier-Brogi (Professeur, Université Lyon 2 Lumière)

Christian Meyer (Chargé de Recherche CNRS, Centre de Médiévistique Jean-Schneider)

Anne-Orange Poilpré (Maître de conférences, Université de Lorraine)

Colette Stévanovitch (Professeur, Université de Lorraine)

\section{Comité éditorial :}

Hélène Aubriet (Maître de conférences, Université Montpellier III)

Catherine Delesse (Professeur, Université de Lorraine)

Dominique Hascoet (Agrégée, Université de Lorraine)

Elise Louviot (Docteur, Université de Lorraine)

Philippe Mahoux (Maître de conférences, Université de Lorraine)

Colette Stévanovitch (Professeur, Université de Lorraine)

\section{Contributeurs :}

Rosa Benoit-Meggenis (Maître de conférences, Université Montpellier III)

Laurent Balon (Docteur, Université de Caen Basse-Normandie)

Paul Cavill (Maître de conférences, University of Nottingham)

André Crépin (Institut de France)

David Dominé-Cohn (Doctorant, Ecole des Hautes Etudes en Sciences Sociales)

Justine Firnhaber-Baker (Maître de conférences, University of St Andrews)

Susannah Fisher (Maître de conférences, Rutgers University)

Marie Formarier (Docteur, Université Montpellier III et Ecole des Hautes Ecoles en Sciences

Sociales)

Caroline Foscallo (Docteur, Université de Genève)

Estelle Ingrand-Varenne (Doctorante, Université de Poitiers)

Midoriko Kageyama (Doctorante, Université Paris IV-Sorbonne)

Blandine Longhi (Docteur, Université Paris IV-Sorbonne)

Elise Louviot (Docteur, Université de Lorraine)

Anne Mathieu (Maître de conférences, Université Montpellier III - Paul Valéry et IDEA, Interdisciplinarité Dans les Etudes Anglophones, Université de Lorraine)

Vanessa Obry (Docteur, Université de Provence et Université de Nantes)

Natalia I. Petrovskaia (Doctorante, University of Cambridge et Ecole Pratique des Hautes Etudes)

Lucien Reynhout (Chercheur, Bibliothèque royale de Belgique et Université Libre de Bruxelles)

Anna D. Russakoff (Maître de conférences, American University of Paris)

Olivier Simonin (Maître de conférences, Université de Perpignan et CRIDAF, Centre de Recherches Interculturelles sur les Domaines Anglophones et Francophones, Université Paris 13)

Alison Stones (Professeur, University of Pittsburgh)

Sarah Wilkins (Doctorante, Rutgers University)

Martine Yvernault (Professeur, Université de Limoges)

\section{(C) 2012, Brepols Publishers n.v., Turnhout, Belgium.}

All rights reserved. No part of this publication may be reproduced stored in a retrieval system, or transmitted, in any form or by any means, electronic, mechanical, photocopying, recording, or otherwise, without the prior permission of the publisher.

$\mathrm{D} / 2012 / 0095 / 158$

ISBN 978-2-503-54749-7

Printed on acid-free paper 


\title{
The Construction is/bið to: \\ A Syntactic Formula to Express Prescription and Earmarking
}

\author{
Olivier Simonin
}

Université de Perpignan \& CRIDAF, Université PARIs 13

Cet article propose une analyse grammaticale, sémantique et diachronique de la construction is/bið to en vieil-anglais, à partir du corpus deprose York-TorontoHelsinki corpus of Old English Prose. Une compréhension fine de la syntaxe de cette formule permet d'apprécier la souplesse syntagmatique qu'elle autorise. Les différents sens de is/bið to mis en évidence apparaissent liés, ce qui nous conduit à proposer un scénario diachronique pour leur développement, où l'on voit que le sens déontique, prescriptif, dérive de premiers emplois radicaux (vébiculant ce que j'ai appelé l'usage destiné), tout en étant influencé par son recours très fréquent dans des traductions de textes latins. L'importance de cette influence se mesure également à travers l'émergence tardive d'un nouvel emploi de is/bið to, initialement utilisé afin de rendre le futur périphrastique du latin.

\section{Introduction}

The is/bid to construction is the Old English structure from which the modern is to construction ${ }^{1}$ is historically derived. It is illustrated by contemporary utterances like No one is to blame or They are to meet at 2 p.m. tomorrow. As a construction, it is a pattern of linguistic forms co-occurring with some

\footnotetext{
${ }^{1}$ For a description of its uses see e.g., Geoffrey Leech, Meaning of the English Verb, $2^{\text {nd }}$ ed. (London: Longman, 1987 [1971]) or Olivier Simonin, 'Relatives infinitives et constructions apparentées,' Université de Paris IV - Sorbonne, 2007, pp. 112-113, available at: <http://www. theses.paris4.sorbonne.fr/simonin/paris $4 / 2007 /$ simonin/html/index-frames.html $>$ (last visited on $01 / 03 / 11)$.
} 
degree of fixity to express a given meaning - root modal prescription in this instance. I rely on Goldberg's definition of constructions ${ }^{2}$, which can accommodate syntactic formulae as abstract linguistic patterns conveying constant meaning:

LEARNED PAIRINGS OF FORM WITH SEMANTIC OR DISCOURSE FUNCTION, including morphemes or words, idioms, partially lexically filled and fully general phrasal patterns. ${ }^{3}$

The formal aspect of the construction minimally includes the following: is/ $b i ð$ to + (inflected) INFINITIVE + SUBJECT

$I s / b i$ to is always conjugated (the form of the verb is finite) and a dative complement sometimes precedes it. In semantic terms, the construction most often denotes root modality: a necessity or obligation is reported, which does not originate from the speaker. Yet when the speaker obviously endorses it, the discourse function of the construction can be (and often is) exhortative; it is then not just used to state a prescription. Prescription is taken in a broad sense so as to include religious, societal and other norms alongside epistemological instructions (beliefs to be held).

Many previous accounts perhaps take too much for granted because this construction is clearly akin to its present-day reflex. Even Mitchell ${ }^{4}$ simply notes that is/bið to could be used in conjunction with infinitives ${ }^{5}$ to express necessity or obligation, without providing a precise semantic characterization or contrasting the construction with others, or committing himself to a definite grammatical analysis (what I call SUBJECT is labelled subject/object). The more detailed and systematic corpus-based account proposed in this paper is meant to fill the gap.

Drawing on the York-Toronto-Helsinki Corpus of Parsed Old English Prose (YCOE for short), as well as a few other sources, to substantiate some of my claims, I investigate the syntax, function and evolution of this particular construction throughout the OldEnglish period. The choice of a prose corpus is justified on the grounds that it exemplifies uses that mirror more closely everyday usage than poetry, and ensures more accuracy when tracing the emergence of new uses. I start with a grammatical analysis of the construction (1), proceed to a semantic account with some diachronic considerations (2), and lastly tackle the question of a potential Latin influence on its development (3).

\footnotetext{
2 Adele E. Goldberg, Constructions at Work: the Nature of Generalization in Language (New York: Oxford University Press, 2006), p. 6.

3 The subject can occur before the conjugated form of beon/wesan, but this is rather infrequent.

${ }_{4}^{4}$ Bruce Mitchell, Old English Syntax, 2 vols. (Oxford: the Clarendon Press, 1985), I, pp. 394-396.

5 Mitchell remarks that when two infinitives follow is/bið, the second can be a bare infinitive (p. 394).
} 


\section{Grammatical description of the construction}

In this section I introduce the is/bið to deontic construction and its main syntactic variants, beginning with the optional presence of a dative complement and the grammatical classification of its subject constituents (1.1). I then consider the alternation between wesan and beon (is/bið) and their various forms in this construction (1.2), before returning to cases in which the subject is a cataphoric pronoun followed by an extraposed constituent (1.3).

\subsection{Complements and subjects}

Let's start with a typical occurrence of the is/bid to construction:

1. Us is to smeagenne pæt word pe he cwæð

We have to ponder the words he said.

(Ælfric's Catholic Homilies I, 254.3) ${ }^{6}$

This occurrence instantiates the relevant syntactic pattern: is is a finite form of wesan followed by a to-infinitive (that is - to be precise - to and the inflected form of the infinitive, which typically ends in -enne) and the nominative subject Fat word De he cwad. Furthermore, the nominative noun phrase (NP) is also understood as the implicit object of the infinitive - it designates the same entity as the one that would have been associated with the verb smeagan had it had an object ('words'). This holds true for all the subjects of the is/bið to construction.

The initial dative NP, us, indicates who is under the obligation mentioned. Its presence is optional though, as two other examples by Ælfric show:

2. Is eac to gehyrenne hu ða leoda wunnon ymbe ðæs halgan lic him betwynan pearle

It must also be heard how valiantly the people fought, around the holy body (between them).

(cocathom2, +ACHom_II,_39.1: 297.314.6769) ${ }^{7}$

3. Is eac to witene ðæt sume gedwolmen wæron ðe woldon awurpan ðealdan $x$

It must also be known that there were heretics that wanted to overthrow the old law.

(coprefgen, +AGenPref: 101.69)

Whoever the obligation bears on is readily retrieved from the context, though it may be difficult to give a precise and definite answer when obligation has a generic scope, as in (2) and (3). Quite typically, the audience or men in

\footnotetext{
${ }^{6}$ Quoted by Mitchell, p. 395.

7 All the occurrences with a reference starting with co are from the YCOE. All the text references from YCOE to be found in the paper may be found at the end of this paper.
} 
general are meant. Note that the same ambiguity does arise with dative $U_{s}$ in (1). Concerning optional dative complements, Visser writes that the is/bid to construction is most often found without them in Old English as well as in Middle English, ${ }^{8}$ whereas Mustanoja expresses an opinion to the contrary. ${ }^{9}$ The texts not translated from Latin in YCOE show an overall bias towards the occurrence of the construction without any dative complement ( 51 occurrences out of 86 lack dative complements - i.e. $40.7 \%$ occur with them), while the bias for texts translated from the Latin is even more significant and conspicuous (out of the 39 first occurrences in Bede's Ecclesiastical History, for instance, only 6 are found with a dative complement, amounting to $15 \%$ ).

Returning to (2) and (3), those utterances show that the subjects that occur in the $i s / b i d$ to construction are not necessarily NPs with determiners clearly marked as nominative. The subject of (2) is a wh-clause (bu da leoda wunnon...) that can be parsed as an NP since it is a free relative clause (without any antecedent). Similarly the subject of (3) is a that clause (Jat sume gedwolmen waron), which formal linguists do not parse as an NP. ${ }^{10}$

Now, if a construction includes a subject and the copular verb (beon/wesan), one needs to address the question of whether or not the verb has a complement and what its nature is. Unless taken in its purely existential sense, the copula licenses two arguments. I therefore analyse the to-infinitival clause in this construction as the second argument of beon/wesan, i.e. its complement.

\section{$1.2 \mathrm{Beon} /$ wesan}

The distinction between beon and wesan is only made in the present tense. The preterite paradigm does not allow for any such alternation, and only wesan forms can be used. Beon forms can occur, but they are fairly uncommon. The general rule is that beon forms appear when they have a future sense or indicate a gnomic present. ${ }^{11}$ This applies fully to the beon/wesan to construction.

4. Ne nan preost Purh dysig ne drynce ungemetelice ne nænne mann ne neadige to mycclum drynce. ForPan Pe he sceall beon gearo gif cild bið to fulligenne oððe man to husligenne Pæt he hæbbe his gewitt.

\footnotetext{
${ }^{8}$ Frederick T. Visser, An Historical Syntax of the English Language. Part III: Syntactical units with two verbs, first half (Leiden: E. J. Brill, 1969), p. 1457.

9 Tauno F. Mustanoja, A Middle English Syntax. Part I: Parts of Speech, Mémoires de la société néophilologique de Helsinki 23 (Helsinki: Société Néophilologique, 1960), p. 520.

10 Peter H. Matthews, Syntactic Relations: A Critical Survey (Cambridge: Cambridge University Press, 2007), pp. 39-49.

11 See e.g., Richard Marsden, The Cambridge Old English Reader (Cambridge: Cambridge University Press, 2004), p. 383.
} 
No priest should drink immoderately through foolishness, nor should any man compel him to much drinking, for he must be ready in case a child is to be baptised or a man to receive the Host, so that he has his whole mind.

(colwsigeXa, +ALet_1_[Wulfsige_Xa]: 74.89)

Bið is used here because the present is gnomic, since it refers to situations that are always likely to happen.

The verb beon/wesan needs to be tense-marked when used in conjunction with a to-infinitive. It can be conjugated in the subjunctive mood (5) and in the preterite (6):

5. And smeage gelome hwæt him sy to donne and hwæt to forego after Godes rihte.

And [they] often pondered what they were to do and what to forgo according to God's law.

(coinspolX, WPol_2.1.1_[Jost]: 19.27)

6. Hi pa heora bicop rædes befrunon hwæt him be pam to donne wære.

They sought their bishop's advice concerning what they were to do about that.

(cocathom1, +ACHom_I,_34: 466.20.6695)

Yet there is another constraint bearing on the construction, as it is incompatible with the imperative mood. This is presumably explained by the observation that it already conveys an almost identical illocutionary force.

\subsection{Cataphoric pronouns as subjects}

Subjects can also be dummy elements whose function is to replace a logical, extraposed subject.

7. Hit is to gelyfenne pæt Drihten mihte on anre tide dæges geseon ealles pises middangeardes wynsumnessa, ge on golde ge on deorwyrpum hræglum.

It is to be believed that the Lord was able to see, during the space of one day, all the delights in this world, whether in gold or in costly raiment.

(coblick, HomS_10_[BlHom_3]:31.67.406)

The personal pronoun hit is the grammatical subject. Its function is to make it possible for the logical subject (bat Dribten mibte on anre tide dages geseon...) to be extraposed. Demonstrative pronouns can also be used to the same effect:

8. Ac Det us is to gePencenne Pæt ure Drihten æfter Pæm fulwihte fæste...

But we have to keep in mind that our lord fasted after being baptised.

(coblick, HomS_10_[BlHom_3]: 27.26.377)

An alternative account of these constructions including extraposed constituents posits that their grammatical subject is a cataphoric pronoun, pointing 
toward or somehow heralding the logical, extraposed subject ${ }^{12}$. Pat is not the only demonstrative that can be used in this context instead of Hit. The deictic Đis is found as well:

9. Đis is to smeagenne hwi sy mare blis be gecyrredum synfullum ponne be unscildigum rihtwisum.

It [lit. this] is to be thought over why there is more sport for the inconstant and sinful than for the innocent and righteous.

(cocathom1, +ACHom_I,_24: 372.48.4698)

Extrapositions are normally restricted to cases in which the logical, extraposed subject is clausal - whether it is a that-clause, as in (7) or (8), or a free relative as in (9). YCOE contains some exceptions however, such as (10):

10. Ac God hi het syðpan Sarra pæt is ealdor pæt heo nære synderlice hire hiredes ealdor geciged ac forðrihte ealdor pæt is to understandenne ealra gelyfedra wifa moder.

But God called her Sarra, which is leader, so that she was not simply named the leader of her household but the direct leader - that is to say [lit. understand] the mother of all living women.

(cocathom1, +ACHom_I,_6: 225.36.1083)

Fat is to understandenne... is a set phrase, reminiscent of and very probably related to the present-day That is to say... The literal meaning of the construction in (10) is: 'the mother of all living women is to be understood' or, without the archaic use of is to: 'one/you must understand the mother of all living women'.

It remains something of a mystery why it was felt necessary to resort to cataphoric pronouns and extrapositions with is/bið to. I speculated ${ }^{13}$ that this probably had to do with the incipient rigidification of word order and the resulting structural pressure towards having subjects before verbs. Yet it seems that the acceptability of cataphoric pronouns dates back to earlier than expected. The two examples from the Blickling homilies suggest that cataphoric pronouns may have already been attested with is/bið to in King Alfred's time. Although this does not fully invalidate the rigidification account (rigidification being an ongoing process throughout the history of English), the latter is partial at best. My educated guess would now be that demonstrative pronouns were probably initially used to emphasise the state of affairs that they point to, and that the pat clause also refers to, thereby contributing to focalizing the clause and its content, which is always discourse-new. Hit, on the other hand, seems to appear (around the same time) as a mere variant of the construction

\footnotetext{
12 For an analysis of it in extrapositions see Pierre Cotte, L'explication grammaticale de textes anglais, $2^{\text {nd }}$ ed. (Paris: Presses Universitaires de France, 1998 [1996]), pp. 206-207.

13 Olivier Simonin, 'Relatives infinitives et constructions apparentées,' pp. 551-552.
} 
with no cataphoric pronoun, in conditions that are free to a large extent. Why various cataphoric pronouns could be used and what were the fine-grained semantic differences between them in conjunction with is/bið to would require more substantial data to draw any firm conclusions.

\section{Meaning and competing patterns}

This section provides a semantic account of the construction (2.1), explores its meaning further by contrasting it with habban to + (inflected) INFINITIVE (2.2), discussing predicative to-infinitives that do not express prescription (2.3), and proposes a semantic and diachronic connection between those infinitives and the is/bid to deontic construction (2.4).

\subsection{Obligation and necessity}

In semantic terms, is/bið to is characteristically used to impart a deontic prescription, as in (1) and (9). It is then often coupled with an exhortative function when the speaker endorses the obligation. The instructions to ponder over religious quotations or problems evoked by Ælfric directly reflect what men or believers ought to do. Though he urges his fellow men to do so, his injunction comes at a second remove, and is justified by higher authority, or what it is fitting to do - the former implying the latter. Correlatively, the construction is also used when what should be done in a particular circumstance is at stake (5), as when laymen defer to a well-established authority to obtain instructions (6). It then appears that the deontic meaning of is/bið to is close to today's ought to and should, as it indicates what it is fitting or appropriate to do, though presumably with a much stronger sense of obligation.

This account equally applies when the inflected infinitive is gebyrenne (2), witenne (3), gelyfenne (7), or understandenne (10), i.e. when the infinitive verb implies comprehension, belief or acquired knowledge. Yet the root modality can often be construed as having a dynamic component and expressing necessity. No possibility is deemed available except understanding or believing in the way envisaged, to take up the last two examples. There is no other choice but the one prescribed. The order of things is such that there is no alternative and, as a result, it is not clear that deontic obligation remains the primary modal meaning.

\subsection{Habban to}

According to Mitchell, ${ }^{14}$ habban could not be used to denote obligation or necessity in conjunction with to-infinitive clauses as complements. Rather, he analyses NPs in sequences habban $+\mathrm{NP}+$ to-infinitives as objects of habban

${ }_{14}$ Bruce Mitchell, 401-402. 
which is taken in its primary sense, 'possess', 'own'. Denison ${ }^{15}$ rightly points out that only by assuming that the NP pertains to the to-infinitive is it possible to interpret the construction as conveying obligation.

The corpus contains a rare counter-example to Mitchell's claim, in which the NP cannot be argued to relate to habban directly and a strong sense of necessity is present:

11. Anes dæges færeld pu hæfst to siðigenne.

You have to arrange for [lit. travel] a day's journey.

(cocathom2, +ACHom_II,_22: 195.176.4331)

The context is the following: Saint Fursey, having been taken to Heaven, enters into a discussion with priests, after angels have warned him that he must return to the temporal world. The priests remind him of the relevant obligation in (11) with a direct speech utterance. Of course, one can argue that the modal meaning of habban to pertains to necessity rather than obligation, and so to dynamic and not deontic modality. Under this reading, the priests take for granted the fact that Fursey will return, which will necessarily be the case by divine decree. This is consonant with Sweetser's general view of modals historically evolving from dynamic to deontic modality ${ }^{16}$ (i.e. non-epistemic necessity to obligation as far as habban to is concerned), as this early example of the modal construction is compatible with a dynamic necessity construal. In addition, the deontic reading of (11) is also inferred from the fact that the speakers are construed as ratifying the obligation conveyed by the angels to Saint Fursey, to whom the priests seem to reiterate the deontic constraint as they address him as $p u$.

Yet, whatever the interpretation one favours, why the competing is/bið to construction was not used remains an issue Why does one fail to find, instead of (11), pe is to sidigenne anes deges fereld? I can only put forward conjectures, not knowing whether the alternative would have been grammatical: perhaps (11) does not easily fall under the concept of prescription, or exhortative implications had to be cancelled, or the role of the addressee had to be highlighted as having the obligation or being bound to leave. It should be borne in mind that offering a fine-grained analysis for the constructions under examination is rendered difficult by the paucity of the data and the lack of informants from whom acceptability judgements could be elicited.

Virtually all the occurrences where habban is used with a to-infinitive convey a meaning of possibility (capacity). (12) is typical in this respect:

15 David Denison, English Historical Syntax: Verbal Constructions (London: Longman, 1993), pp. 316-317.

16 Eve Sweetser, From Etymology to Pragmatics (Cambridge: Cambridge University Press, 1990). 
12. Đa næfde Martinus nan ðing to syllenne pam nacedan ðearfan pe ðær swa ðearle hrymde buton his gewædum pe he wel behofode.

Then Martin did not have anything to give to the naked pauper that suffered so cruelly from the cold, except his garments that he needed quite.

(cocathom2, +ACHom_II,_39.1: 289.29.6534)

Quite clearly, what is meant is Martin could not give anything to the pauper except his clothes; the to-infinitive is a relative clause.

In sum, although one occurrence of habban to meaning obligation or necessity (in late $\mathrm{OE}$ ) has been found in YCOE, the construction is an unlikely competitor to is/bið to. More serious candidates would have been sculan and motan, at least in terms of frequency. They could also convey root necessity/obligation, but in a more subjective fashion. In particular, speakers could be deontic sources and directly issue obligations without invoking a higher-order prescription. Yet to avoid being taken too far afield, let us leave modal verbs now.

\subsection{Predicative to-infinitives and earmarking}

Predicative to-infinitives had been in use since the dawn of Old English not to convey prescription, but to indicate what a subject referent has been earmarked for:

13. Đonne is ðes londes ðe ic higum selle, XVI gioc ærðe londes \& medwe all on æce ærfe to brucanne ge mine dei ge æfter swæ to ationne swæ me mest red \& liofast sie.

Of this land I that I bequest to him/them, (there) are XVI "yokes" of field and meadow to enjoy during my day and also to dispose of afterwards, as it pleases me most.

(codocu2, Ch_1510_[Rob_6]:20.11)

The land in question is earmarked for a given use: it is to be disposed of by someone else. The to-infinitive is a predicative complement with an adverbial purposive meaning tinged with a sense of possibility, as the land is bequeathed so that the future owner can/will be able to enjoy it and dispose of it. This is one of the oldest occurrences in YCOE. The written document dates back to 850-950 (period 2 for Old English in the Helsinki corpus), but the composition of the text itself is prior to 850 (period 1). This leads me to entertain a strong suspicion that such predicative to-infinitives are already found at the very beginning of Old English.

Similar infinitives, occurring adverbially with verbs other than beon/wesan, were current and even frequent in comparison.

$14 . . . \&$ betæhte him eall pæt he ahte to bewitanne.

And he made over to him all that he possessed for him to administer.

(cogenesiC, Gen_[Ker]: 39.4.149) 
Perhaps the infinitive in (14) could have been more explicitly translated 'so that he would (be able to) administer what he possessed.' The notion of earmarking is also fully relevant to account for the meaning of the infinitive. ${ }^{17}$

Yet only when the to-infinitive is predicative can the root modality expressed through earmarking pertain to necessity, and not to possibility:

15. Gepencean we eac gif oper nyten wære to haligenne \& geteod to pon ecan life ponne onfenge he heora hiwe

Let us think too that if other animals were to be saved, and lifted to eternal life, then he would have taken on their form.

(coblick, HomS_10_[BlHom_3]: 29.34.381)

That God may have earmarked animals to be saved is considered for the sake of argument, only to be rejected afterwards. If that had been true, animals would then have fallen under the dynamic necessity that can be paraphrased 'if animals had to be saved'. This illustrates how earmarking can lead to root, dynamic necessity interpretations of the construction. Furthermore, earmarking can be understood as referring to the natural order of things, from which necessity stems:

16. Be pam we forhtiað fela to sprecenne for pan ðe Gode anum is to gewitenne hu heora ungesewenlice gecynd buton ælcere besmitennysse oððe wanunge on ecere hluttornysse purhwunad.

Concerning that we fear to speak much, because God alone is (meant) to know how their invisible nature without any defilement or injury in eternal purity remains. (cocathom1,+ACHom_I,_36: 486.19.7146)

The following excerpt from Beowulf argues in favour of a very early use of predicative to-infinitives to express necessity:

17. [...] Denum eallum wæs,

winum Scyldinga weorce ${ }^{18}$ on mode

to geðolianne, ðegne monegum,

[...] syðan Æscheres

on Pam holmclife hefelan metton

${ }^{17}$ I refer the reader to my 2011 account of such infinitives in Present-Day English, where I introduce the notion of earmarking and propose an in-depth analysis of such 'weakened' purposive clauses: Olivier Simonin, 'Adverbial and relative infinitives,' Journal of English Linguistics (to be published).

${ }_{18}$ As Scragg points out, weorce is in the instrumental case: see Donald G. Scragg, 'The nature of Old English verse', in The Cambridge Companion to Old English Literature, edited by Malcom Godden and Michael Lapidge (Cambridge: Cambridge University Press, 1991), 55-70, p. 64. In my conception however, it is overtly marked as the instrumental complement of the infinitive to geðolianne (presumably for alliterative purposes, as the sounds at the beginning of the syllables Scy-and -ce are similar), but is still the grammatical subject of was. 
For all the Danes, for the friends of the Scyldings,

For many a thegn, there was much suffering

To be endured in the mind

When they met with, on the cliff beside the water,

The head of Eschere.

(Beowulf 1417-1421) ${ }^{19}$

The Danes who saw Æschere's head had no choice but to sustain mental pain. There was suffering for them, and it had to or was bound to be endured as a result. In this example, necessity does not seem to be too remote from deontic obligation.

\subsection{Prescription and earmarking}

The notion of earmarking can in fact be extended to cover prescription and account for occurrences like (1), which convey deontic modality and a particular brand of earmarking. (1) might have been translated 'We are meant to ponder the words he said'. However, for descriptive purposes, it is important to keep the two notions separate. I will keep the term prescription for deontic obligation.

Considering the semantic propinquity of the two beon/wesan to constructions expressing prescription or earmarking, I hypothesize in the light of the available data that they are related and, more precisely, that the prescription construction is historically derived from the earmarking one. The division line between them may be fuzzy at times, as a sense of necessity is liable to appear with the former, or a nuance of obligation with the latter. The is/bid to construction is best regarded as a polysemic unit the meanings of which may partly overlap.

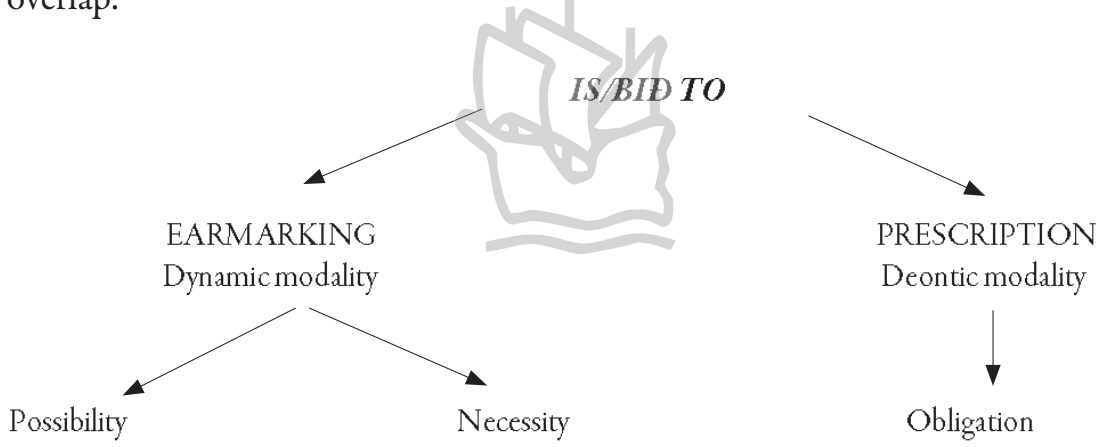

${ }^{19}$ George Jack, Beowulf: A Student's Edition (Oxford: Oxford University Press, 1994), pp. 112 114. 
More interestingly, YCOE contains a few examples where there seem to be a genuine ambiguity or some overlap between the two interpretations:

18. Gif feorcund mon oððe fremde butan wege geond wudu gonge $\&$ ne hrieme ne horn blawe, for ðeof he bið to profianne: oððe to sleanne oððe to aliesanne. If a strange or foreign man goes from the road and through the wood, without shouting or blowing his horn, he is to be deemed a thief/criminal, either to slay or to let free.

(colawine, LawIne: 20.52)

The man must be regarded as a criminal - no other choices are available - or the law is understood as prescribing that he be deemed as such. Both the (dynamic) necessity-reading and the (deontic) obligation-reading are acceptable for the beon/wesan to construction in (18), for which the usual distinction is blurred. Such occurrences might have provided a bridging context ${ }^{20}$ between earmarking and prescription for the construction, enabling it to expand the range of contexts in which it could be found.

\section{Influence of Latin}

Through a discussion of religious writings and translations from Latin, I show that Latin had a substantial influence on the development of the is/bid to construction expressing prescription (3.1). I then address the issue of whether is/bid to was resorted to as a conventional manner of rendering some Latin structures or whether it was genuinely idiomatic (3.2), before commenting on the rise of a new, related employment through a linguistic calque (3.3).

\subsection{Deontic meaning and the influence of genre}

Depending on the genre in question, is/bið to comes up more or less frequently. There is a conspicuous general bias towards the occurrence of the construction in religious writings and homilies. This is not surprising since it is particularly well suited to the prescriptive style characteristic of the genre, replete with exhortative speech acts for which the construction is employed as a recurrent formula.

Yet more strikingly, translations from the Latin exhibit a significant number of is/bit to occurrences. The following table indicates the number of hits out of the total of infinitival clauses (or phrases: IPs) found in YCOE religious texts or excerpts with a sufficient length for them to be significant.

\footnotetext{
${ }^{20}$ Bernd Heine, 'On the role of context in grammaticalization,' in New Reflections on Grammaticalization, edited by Ilse Wischer and Gabriele Diewald (Amsterdam: John Benjamins, 2002), 83-102.
} 
Text

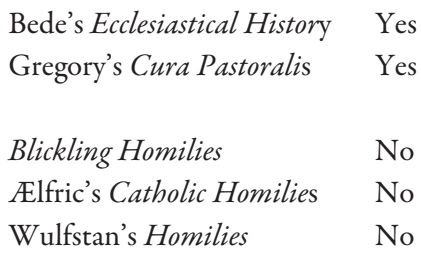

Hits (/IPs)

$\%$

Translation

$71 / 4923$

1.44

$327 / 3400$

9.62

$27 / 3050$

0.89

$42 / 15776$

0.27

$5 / 1889$

0.26

Even in the Old English version of Bede's Ecclesiastical History, the percentage of to-infinitives used in conjunction with is/bið is more than 1.5 times higher than for the Blickling Homilies, which has the highest occurrence rate for a work not translated from the Latin. This overrepresentation of the construction in translations suggests a possible influence of Latin on its development.

Assuming that the earmarking sense of is/bid to is indigenous to Old English and was in all probability also found in Germanic, ${ }^{21}$ it is likely that Latin translations had an influence on the development of its deontic reading. Indeed, Latin had a so-called gerundive construction that specifically meant prescription (obligation/necessity) which was formed with esse + -ndus VERBAL ADJECTIVE. ${ }^{22} \mathrm{Klöpzig}^{23}$ finds that is/bið to is overwhelmingly used to translate esse + -ndus VERBAL ADJECTIVE. This shows that the native construction was felt to be fully compatible with the obligation meaning of the Latin verbal adjective.

A Latin influence on the development of the deontic uses of the construction is highly probable, whether it contributed to its initial rise or not. Conceivably, the semantic continuity between the notions of earmarking and prescription may be sufficient in itself to account for an initial stage when is/ bid to started to express deontic prescription unambiguously. At any rate, its sheer repetition with this meaning in translations from Latin texts (quotations from which would have peppered sermons) must at least have contributed to an overall frequency increase in everyday usage.

\subsection{A closer look at translations from Latin}

A note of caution should be sounded here. In translations, is/bid to would sometimes appear while the Latin text did not contain esse + VERBAL ADJECTIVE (or any other gerundive or participial form). Here are two examples taken

\footnotetext{
21 As well as modern reflexes in other Germanic languages: see Olga Fischer, 'The rise of the passive infinitive in English,' in Historical English Syntax, edited by Dieter Katovsky (Berlin: Mouton de Gruyter, 1991), 141-188, pp. 149-150.

22 Simone Deléani and Jean-Marie Vermander, Initiation à la langue latine et à son système, $2^{\text {nd }}$ ed. (Paris: SEDES, 2003 [1975]), pp. 226-227, 262.

23 Walther Klöpzig, 'Der Urspring der “to be to" konstruktion,' Englisch Studien 56 (1922), 378-389, quoted by Olga Fischer, p. 149.
} 
from an Old English translation of Bede's Ecclesiastical History, which I have chosen to compare with their Latin original ${ }^{24}$ :

19. Ecce itque homo est, ut ita dixerim, captivus et liber:

Ono se mon bið, Pæt Pe swa to cweðenne sy, æghwæðer ge gehæfted ge freo:

Well then man is, so to speak, both captive and free.

(cobede, Bede_1: 16.88.23.813)

20. Et quid est aliud contra famem alimenta...

Ond hwæt elles is to secenne wið Pæm hungre nemne ondlifen...

And what else is to be sought for against hunger than food...?

(cobede, Bede_1: 16.78.23.723)

This suggests that, by the time of King Alfred, is/bið to was used quite idiomatically to express obligation, in translated just as in non-translated works. Yet the construction was sometimes resorted to so as to translate Latin structures quite slavishly. As Olga Fischer writes: ${ }^{25}$

When the subject of $b e$ is not the object of the infinitive... the construction occurs only rarely in Old English, and is in all cases a translation of the Latin periphrastic future (esse + urus) or (occasionally) the gerundial construction with ad.

\subsection{Future reference and predestination}

Late in the Old English period, is/bið to could be used to refer to future time idiomatically, albeit it carried strong undertones of predestination. ${ }^{26}$ The grammatical subject of is/bit is then never to be understood as the implicit object of the to-infinitive. The first occurrences of is/bid to in this sense appear in translations from Latin $^{27}$ as an equivalent to the periphrastic future in esse + (turus/-surus) FUTURE PARTICIPLE. (21) illustrates this new development:

21. Ic bidde Pe, Drihten, send Pone Pe du to sendene eart

I pray you, Lord [i.e. God], send the one that you are to send by your own decree. $(\text { Exodus } 4.13)^{28}$

\footnotetext{
${ }^{24}$ For those two examples taken from Bede, the first lines in Latin are from Colgrave \& Mynors's edition: Bede's Ecclesiastical History of the English People, edited by Bertram Colgrave and Roger A. B. Mynors (Oxford: the Clarendon Press, 1969). The Present-Day English translation is from Miller: Thomas Miller, The Old English Version of Bede's Ecclesiastical History of the English People, volume 1, Early English Text Society, Original Series 95 (London: Oxford University Press, 1959 [1890]).

25 Olga Fischer, p. 148.

${ }^{26}$ See W. van der Gaaf. 'Beon and Habban connected with an inflected infinitive,' English Studies 13 (1931), 176-188; Frederick T. Visser, p. 1452.

27 See: Morgan Callaway, The Infinitive in Anglo-Saxon (Washington: Carnegie Institution of Washington, 1913); W. van der Gaaf, p. 176; Olga Fischer, p. 148.

28 Quoted in: Bruce Mitchell, p. 399.
} 
(22) shows that by the end of the Old English period, the traditional syntactic pattern with a grammatical subject coreferential with the implicit object of the infinitive was also used in the same sense:

22. Eall ðis wæs God mid to gremienne \& pas arme leode mid to tregienne All this was bound to enrage God and trouble the poor nation (cochronE, ChronE_[Plummer]: 1104.26.3410)

I have chosen to reinforce the meaning of predestination in both translations, fleshing it out by adding by your own decree for (21) and bound for (22). Such modal colouring is absent from the Latin construction, yet it makes sense when seen in the light of other uses of is/bid to. In particular, predestination is congruent with the notion of earmarking: fate preordains a given outcome which will necessarily happen. Incidentally, one could perhaps argue that (21) and (22) could be accounted for drawing solely on the concept of necessity. In any event, the fact that is/bið to regularly conveyed necessity and obligation gave an interesting semantic twist to the futurity that it came to communicate.

\section{Conclusion}

Is/bid to was not confined to the expression of deontic prescription in Old English. The range of its meaning extended to dynamic modality as well, covering both possibility and necessity in so far as these arise from earmarking, which has been argued to be the original sense of the construction. Fairly late in Old English, is/bio to acquired an additional futurity meaning, though seriously tinged with undertones of necessity and a sense of preordained destiny.

Later developments are fairly well known and easier to trace, though they fall beyond the scope of this paper. In short, with the rise of passive infinitives (i.e. be + PAST PARTICIPLE) and of is/bio to occurrences with subjects that were understood as the implicit subjects of the to-infinitives (the week to come), alongside the ongoing loss of case-marking and the concomitant rigidification of word-order, the syntactic pattern SUBJECT + be to + INFINITIVE came to be seen as the normal one for the construction. As a result, initial dative complements were eventually reanalysed as subjects in the construction (e.g. $\underline{W e}$ are to do these things). The meaning of the construction evolved as well. Perhaps the most telling illustration is that the undertones of predestination underpinning future reference slowly gave way to a weaker sense of pre-arrangement. Yet in spite of all these changes, it is noteworthy that the initial finiteness constraint bearing on the copular verb has been maintained: be must be conjugated in today's construction, which testifies to the resilience of the constraint and the historical memory that constructions may retain. 


\section{YCOE references (by alphabetical order):}

- cobede (Bede's History of the English Church): Thomas Miller, The Old English Version of 'Bede's Ecclesiastical History of the English People', Early English Text Society 95, 96, 110, 111 (London: Oxford University Press, [18901898] 1959-1963)

- coblick (Blickling Homilies): Richard Morris, The Blickling Homilies, Early English Text Society 58, 63, 73 (London: Trübner, [1874-1880] 1967)

- cocathom 1 (Ælfric’s Catholic Homilies I): Peter Clemoes, Ælfric’s Catholic Homilies: The First Series, Early English Text Society s. s. 17 (Oxford: Oxford Univesity Press, 1997)

- cocathom2 (Ælfric's Catholic Homilies II): Malcolm Godden, Ælfric's Catholic Homilies: The Second Series, Early English Text Society s. s. 5 (London: Oxford University Press, 1979)

- cochronE (Anglo-Saxon Chronicle E - Peterborough Chronicle): Charles, Plummer, Two of the Saxon Chronicles Parallel (Oxford: Clarendon Press, [1892-1899] 1965). Reissued by Dorothy Whitelock (Oxford, 1952)

- codocu2 (Charters and Wills): A. J. Robertson, Anglo-Saxon Charters (Cambridge: Cambridge University Press, [1939] 1956)

- cogenesiC (Genesis): Samuel J. Crawford, The Old English Version of the Heptateuch. Alfric's Treatise on the Old and New Testament and His Preface to Genesis, Early English Text Society 160 (London: Oxford University Press, 1922), 444-56. Reprinted with additions by N. R. Ker (1969).

- coinspolX (Institutes of Polity): Karl Jost, Die 'Institutes of Polity, Civil and Ecclesiastical', Swiss Studies in English 47 (Bern: A. Francke, 1959)

- colawine (Laws of Ine): F. Liebermann, Die Gesetze der Angelsachsen (Halle: Max Niemeyer, 1903-1916).Reprinted (Aalen: Scientia Verlag, 1960)

- coprefgen (Ælfric’s Preface to Genesis): Samuel J. Crawford, The Old English Version of the Heptateuch. Alfric's Treatise on the Old and New Testament and His Preface to Genesis, Early English Text Society 160 (London: Oxford University Press, 1922), 76-80. Reprinted with additions by N. R. Ker (1969)

- colwsigeXa (Ælfric’s Letter to Wulfsige): B. Fehr, Die Hirtenbriefe Aelfrics in Altenglischer und Lateinischer Fassung, Bibliothek der Angelsaechsischen Prosa IX (Hamburg: Verlag von Henri Grand, 1914), 1-34. Reprinted with a supplement by Peter Clemoes (Darmstadt, 1966) 


\section{Tables des matières}

Avant-propos 5

Elise Louviot, Pour une approche interdisciplinaire de la formule $\quad 7$ médiévale.

$\begin{array}{ll}\text { Littérature française } & 13\end{array}$

Laurent BALON, Et poignent les chevax des esperons dorez: La formule « éperonner le cheval », le vocabulaire et les épithètes formulaires $\mathrm{du}$ cheval dans Garin de Monglane

Blandine LonghI, Li plus hardiz est couarz devenuz: Les formules mentionnant la peur, indices de l'évolution des chansons de geste ?

Vanessa Oвrу, Ore est Lanval mut entrepris : Formules et construction du personnage dans quelques récits français du $\mathrm{XII}^{\mathrm{e}}$ siècle

Caroline FosCallo, Pain et vin et char et poissons : listes alimentaires et écriture formulaire dans les fabliaux

Midoriko Kageyama, Formules de modestie dans le Quadrilogue invectif d'Alain Chartier

\section{Langues non romanes}

Olivier Simonin, The Construction is/bið to: A Syntactic Formula to Express Prescription and Earmarking

Paul Cavill, Maxims in the Making of a Homily: Formulaic Composition in Archbishop Wulfstan's Notes

André CrépIn, Désignations de Dieu dans les poèmes vieux-saxons Heliand et Genesis

Natalia I. Petrovskaia, La disparition du quasi dans les formules étymologiques des traductions galloises de l'Imago Mundi

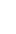

\section{3}

.


Anne Mathieu, Une formule narrative en action : Le Charme des 143 trois bons frères dans deux manuscrits anglais du $\mathrm{XV}^{\mathrm{e}}$ siècle

Martine Yvernault, Formuler et former : les techniques pédagogiques dans quelques traités et poèmes sur les bonnes manières à la fin du Moyen Âge en Angleterre

\section{Inscriptions et manuscrits}

Estelle IngRAND-VARENNE, Formule épigraphique et langue : le cas de hic jacet

Lucien Reynhout, Du bon usage des formules de colophons :

Quelques hypothèses sur leur exploitation méthodologique

\section{Histoire}

Justine Firnhaber-Baker, Formulating Opposition to Seigneurial War in the Parlement de Paris

David Dominé-Conn, Formules et formulation du pouvoir dans le duché de Bretagne : Les lettres de rémission ducales de Charles de Blois et Jean IV de Bretagne, ducs de Bretagne

Rosa Benoit-Meggenis, Le salut de l'empereur et de l'empire : la rhétorique impériale byzantine autour du devoir de prière des moines (IX ${ }^{\mathrm{e}}$-XIII ${ }^{\mathrm{e}}$ siècle)

\section{Arts}

Sarah Wilkins, Adopting and Adapting Formulas: The Raising of Lazarus and Noli me tangere in the Scrovegni Chapel in Padua and the Magdalen Chapel in Assisi

Anna D. Russakoff, The Virgin Hodegetria: an Iconic Formula for Miracle Illustrations in the West?

Susannah Fisher, Formulating Viewer Response: Early Medieval Treasury Bindings

Alison Stones, Formulas and Divergencies in the Illustrations of the Psalter, Nancy, Musée Archéologique MS 249

Marie Formarier, Formules et motifs dans la séquence O Ierusalem de Hildegarde de Bingen : musique ou rhétorique?

Table des illustrations

Table des sources

Index des ouvres et auteurs

Tables des matières 